\title{
Tourist Phenomenon in Geoagiu Spa Region within the Central Metaliferi Mountains
}

\author{
Dombay Ştefan A*, Magyari- Sáska Zsolt ${ }^{\mathrm{A}}$ \\ Received: November 2010 | Revised: November 2010 | Accepted: November 2010
}

\begin{abstract}
The Central Metaliferi Mountains, situated in south-central side of the Apuseni Mountains, have a variety of natural and anthropic touristic potential, but, unfortunately, less known and not enough exploited. After conducting a survey in Geoagiu Spa we specifically recommend the following: increased number of one day tours, which are the main tourist destination in the region, many tours for visiting the major centers of cultural - historical monuments related to our past history, granting economic incentives for organizer of youth groups to attract the youth, diversification of tourist routes with thematic actions: curiosities of nature, environment, organizing sports events with different timetable covering all seasons and all series, attracting local and foreign investors by providing tax incentives and financial programs introducing touristic resort in the international circuit.
\end{abstract}

Keywords: tourist potential, natural and anthropic resources, Western Carpathians, survey

\section{The natural and anthropic resources within the region}

The Central Metaliferi Mountains, situated in the south-central side of the Apuseni Mountains, have a variety of natural and anthropic touristic potential, but, unfortunately, less known and not enough exploited.

The most important natural resources may be grouped as it follows:

- the geological and geomorphologic resources. These are interesting because of the varied petrographic constitution, such as: volcanic cons, forms belonging to the exokarst and endokarst, passes, defiles, and others;

- the climatic touristic fund that is characterized by a temperate climate, with influences from the western air mass, moist in the south, and with sub Mediterranean features in the southwest;

- the hydrographical potential is formed by a dense streams network, but, generally, short, these being affluent of the Arieş, the White Criş (Vaţa, Bucureşci, Stănija) and the Mureş (Ampoi, Certej, Boholt, Gurasada, Valea Roşie). On some of these there are dam lakes: Certej on the Făerag, or lakes for water supply. The Neocene volcanism led to the appearance of some cold mineral springs (Boholt, Şoimuş) and thermal ones (Geoagiu, Vaţa de Jos);

- the fitogeographic fund encompasses numerous characteristic elements of the leafy woods area, and of the coniferous area in the higher regions.

The anthropic resources are especially rich in elements of ethnography and folklore. Within this unity there are three ethnographic sub areas (V. Butură, I978): the Zărand sub area, the Mocănimii sub area and the "Ţara Moţilor" sub area, each of them with valuable characteristic ethnographic elements.

For a better highlighting of region's touristic potential, taking in consideration a few principles, a certain zoning may be done: the highlighting and the concentration of a great number of natural and anthropic sights; the presence of some cater spaces for the tourists, to ensure the access in the area; to ensure some functional networks between the areas, both inside and outside the region.

We mention that this zoning refers exclusively to the researched area:

\footnotetext{
A Gheorgheni University Extension, Faculty of Geography, Babeş-Bolyai University,

* Corresponding author: Dombay Ştefan, e-mail: dombay.istvan@gmail.com
} 
The area of the Ampoiu Valley that is situated at the southern limit of the Trascău Mountains, in the Ampoiului Basin.

The Băiţa-Deva area overlaps both the Căianului Basin and the Mureş Passage till Simeria.

The Brad area that is characterized by the advanced development of the volcanic forms.

The Geoagiu area. As from the researched area this is the best developed, we intend to research this activity in the Geoagiu-Băi spa.

The relief is characterized by the presence of the lime stones that lead to the appearance of some very attractive forms, such as: the Mada Passes, the Cibului Passes, dolinas where the water gathered, forming lakes, for example between Geoagiu-Bai and Geoagiu Sat.

The climate of the spa is continental- temperate with ocean influences. Because of the relief it has a topoclimates of low mountains and hills.

The hydrograph is the most important touristic resource. We refer especially to the thermomineral springs, which are the most important therapy factors, too.

Unlike the attractive resources belonging to the natural framework, which are a gift of nature, the anthropic tourist heritage represents a sum of the elements created by man, for relaxation purposes. Yet, the following fact has to be clearly stated: these were not created on purpose, but, on contrary, in most of the cases these had another purpose (economic, strategic, cultural). In time they have changed their characteristics, becoming proper touristic sights, with a relaxation character.

Among the most important resources from this category we mention:

- religious edifices: the chapel built in Roman style from the X111 ${ }^{\text {th }}$ century and the Orthodox church "Saint Nicholas" from the XVI ${ }^{\text {th }}$ century in Geoagiu-village, the Castle and the church from Sântămăria-Orlea, the Church from Strei from the Xll1th century, the church from Densuş from the Xl1 ${ }^{\text {th }}$ century;

- the memorial house "Ion Budai Deleanu" in the Cigmău village; the memorial museum "Aurel Vlaicu" in the Aurel Vlaicu locality;

- museums (The Ethnographic Museum from Orăştie, the Hunedoara History Museum with the Corvins Castle, the Sarmizegetusa Archaeological Museum, the Brad Mineralogical Museum).

The tourist infrastructure ensures the accomplishment of the tourist consumption, being the most expressive indicator of the economic efficiency and of the touristic potential utilization. Its main function is to satisfy the demand through specific endowments and services in accordance with the raising number of tourists in the spa.
The endowments and services within the tourist infrastructure extended due to the curative efficiency of the thermo-mineral waters from Geoagiu. The endowments for relaxation and cure increased at the beginning of the $\mathrm{XX}^{\text {th }}$ century, when there were built the Germisara, Diana (with covered swimming pool) hotelier complexes and endowments for enjoyment in open air.

\section{Characteristics of tourist demands in Geoagiu spa resort}

The main objectives of this research work were: determining the frequency of tourism in the resort, follow the main motivations of tourists arrived in the resort, establishing the duration of stay and preferences for certain forms of accommodation, determining the transport used by tourists to visit the resort, setting the decisive factor for choosing Geoagiu Spa resort, to determine the main segments of tourists by gender, age, socio-professional categories, marital status and the origin of tourists

The aim of this research are to investigate the causes which led the tourists to seek for the services of this tourist resort, identifying the main reasons that determined the actual tourism forms, and to verify that the tourist market area has a strong seasonal pattern, being attended predominantly summer, the transport used to come to the resort are mainly based on vehicles, and that for tourists arriving in resort, the hotels represents the preferred accommodation.

For this research we have examined a community of 529 tourists in the resort in two stages (in January - February. 2008 respectively April I5 to April 30, 2009). Tourist came to Geoagiu Spa from the following counties (Fig. I).

Among the subjects covered by the investigation, $59 \%$ are men and $41 \%$ are women. Tourist belongs to the following age groups (Fig. 2).

After socio-professional category and marital status the tourists presents the distributions shown in Fig. 3 and 4.

The tourists participating in survey, $42 \%$ practice tourism in an organized way.16.7\% of them come to resort through various agencies, and I0.7\% by other forms of tourism. Most come on their own (58\%).

\section{Types of information related to Geoagiu Spa resort}

They are: advertising I8.7\% 39.1\% acquaintances advice, information obtained from travel agencies I5.2\%, other ways (previous visits) $27 \%$.

Image that presented by those who had previous visits to the area have largely contributed to the choice of resort. Significant share holds media, advertising and information obtained through 

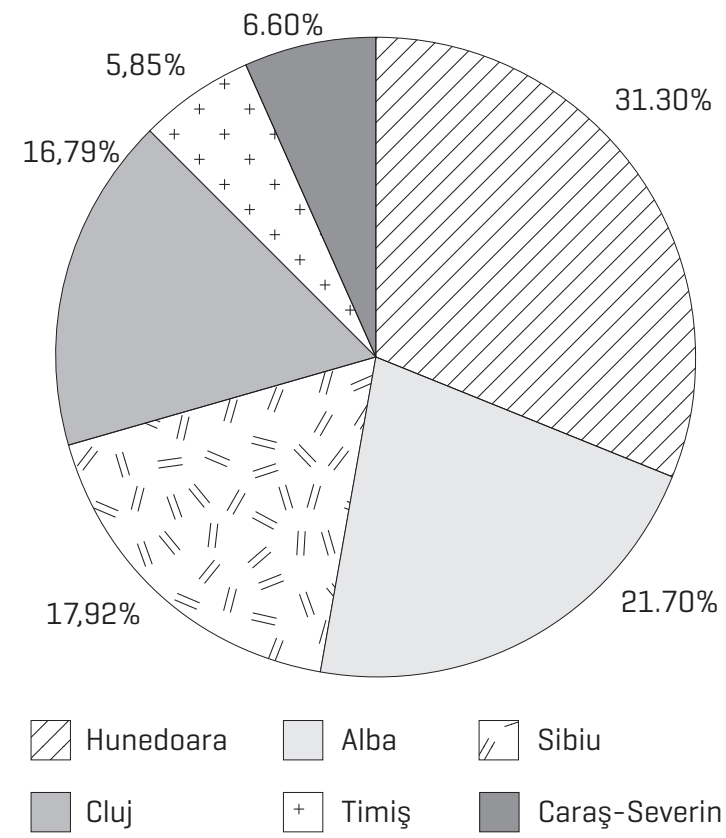

Figure 1. Counties of origin of tourists to the Geoagiu Spa

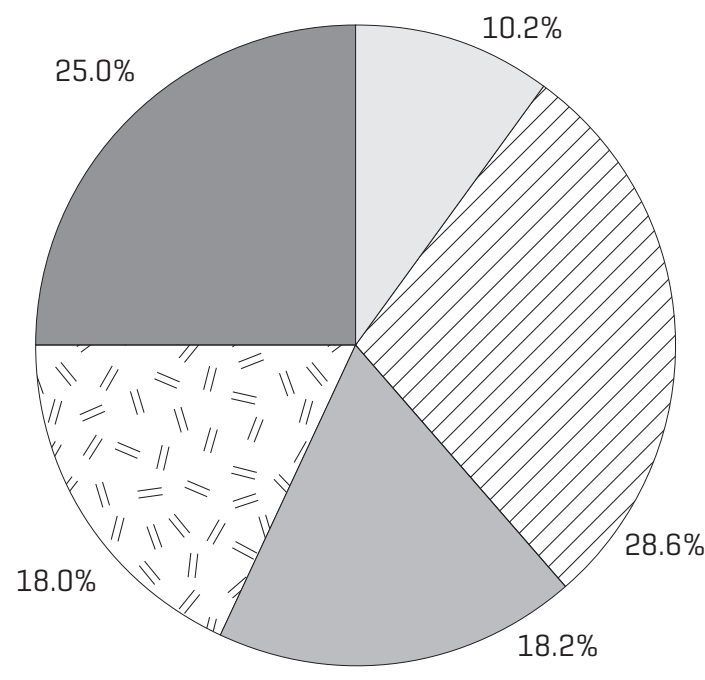

workers $8 \Delta$ with secondary education

with higher education $\quad \square$ pupils, students

pensioners

Figure 3. Socio-professional category for resort guests at Geoagiu Spa

travel agencies. Various information ways are received differently depending on a number of individual variables like age, gender, level of training. Thus the age perception is different.

As shown in the figure (Fig. 5), tourists having an age up to 20 years were mainly informed by other ways (60.9\%) and acquaintances (39.1\%). The age group 2 I to 29 years receives information particularly through acquaintances (4I.5\%), other media -
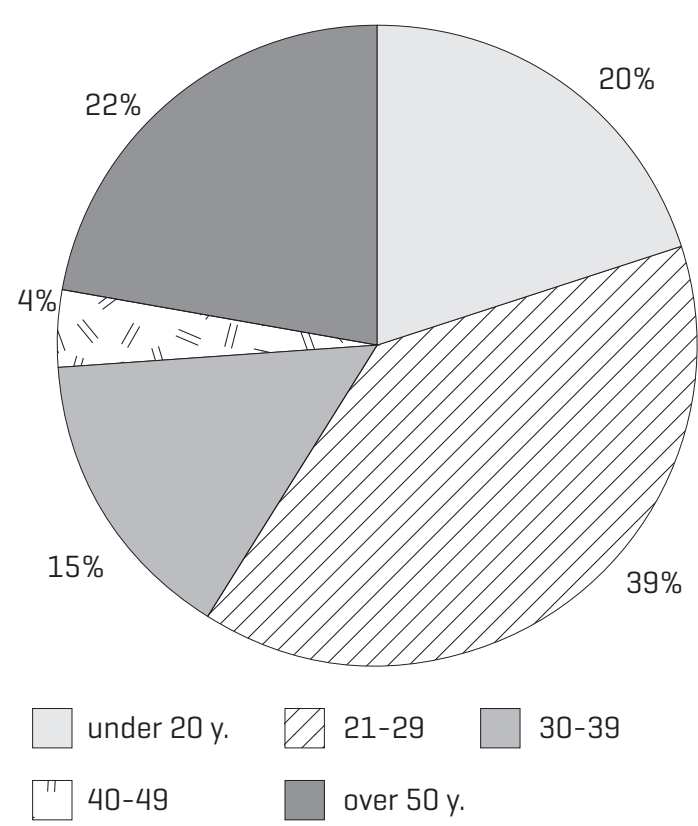

Figure 2. Tourists at Geoagiu Spa categorized on age groups

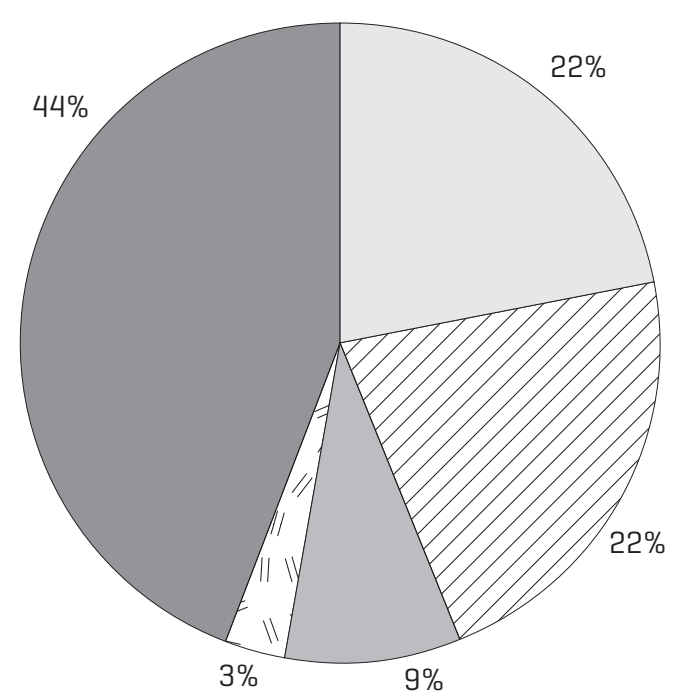

married without children $\nabla A$ married with 1 child married with 2 child $\quad \square^{\prime \prime}$ married with 3 child unmarried

Figure 4. Marital status of tourists to the Geoagius Spa

previous visits (25\%). For those aged 30-39 years, the most important information channels are acquaintances $(39.5 \%)$ and previous visits (26.3\%). In the group aged 40-49 years greatly increase the information received from travel agents. That way information increases in importance in the age group between 50-59 years (40\%). It can be noted that regardless of age, a particular influence on information about the resort is the knowledge and advice of prior visits. 


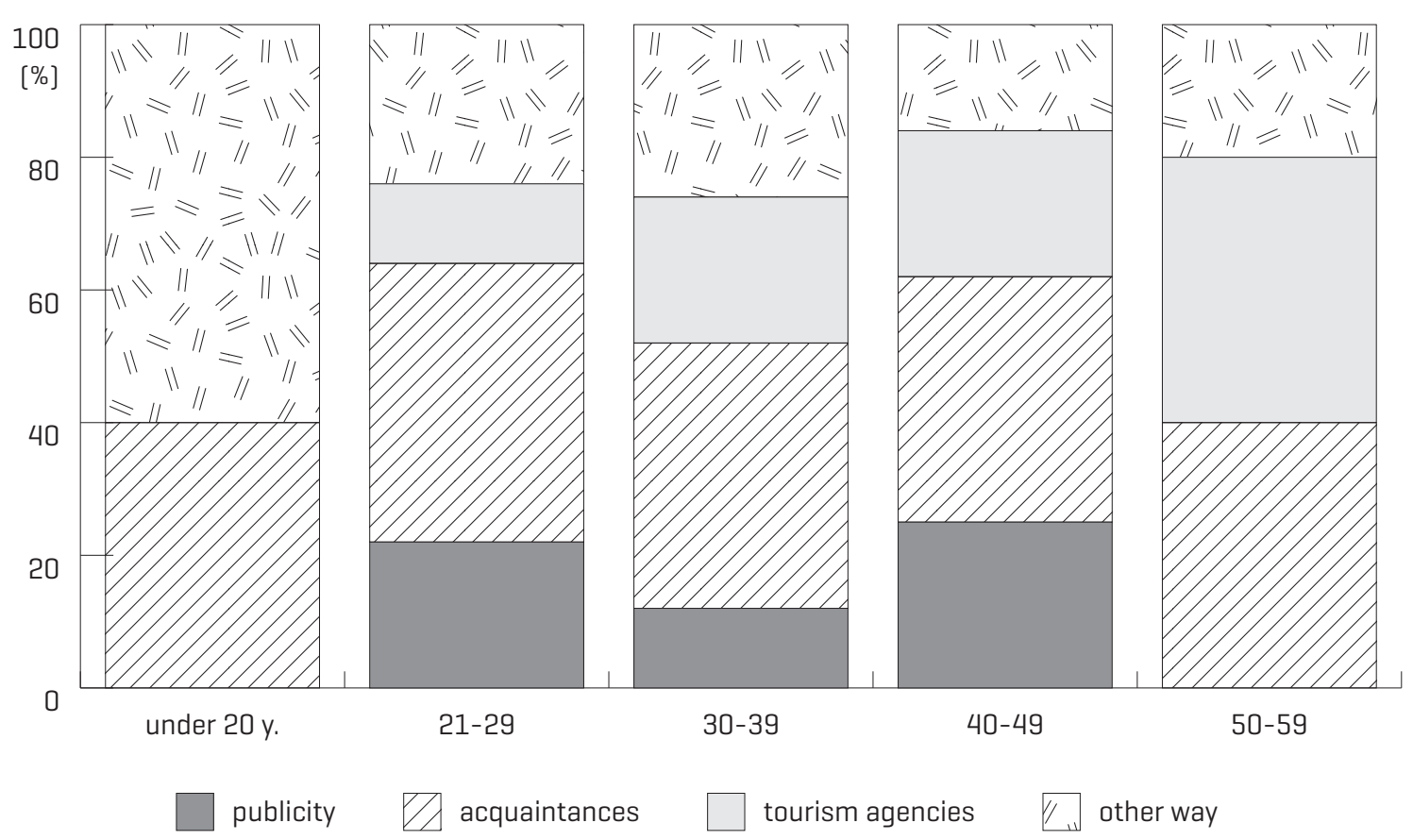

Figure 5. Ways of information on age groups at Geoagius Spa

Of those mentioned above that Geoagiu Spa resort has no appropriate promotional activity. But this phenomenon - unfortunately - is apparent in other tourist resources in Romania.

The information is received differently depending on the level of training.

Thus, workers and teachers in secondary education are influenced higher than students by travel agencies, students and persons with higher education prefer to ask those who were in the resort.
We can notice the following conclusions: apart from the fact that promotional materials are few tourists do not really have confidence in them, which means that those who drafted them show a lack of professionalism.

Diversity and quality is one of the main factors of competitiveness and therefore a fundamental problem facing the tourist industry in general, on which regression, stagnation or prosperity of the whole future tourism activities. National and in-

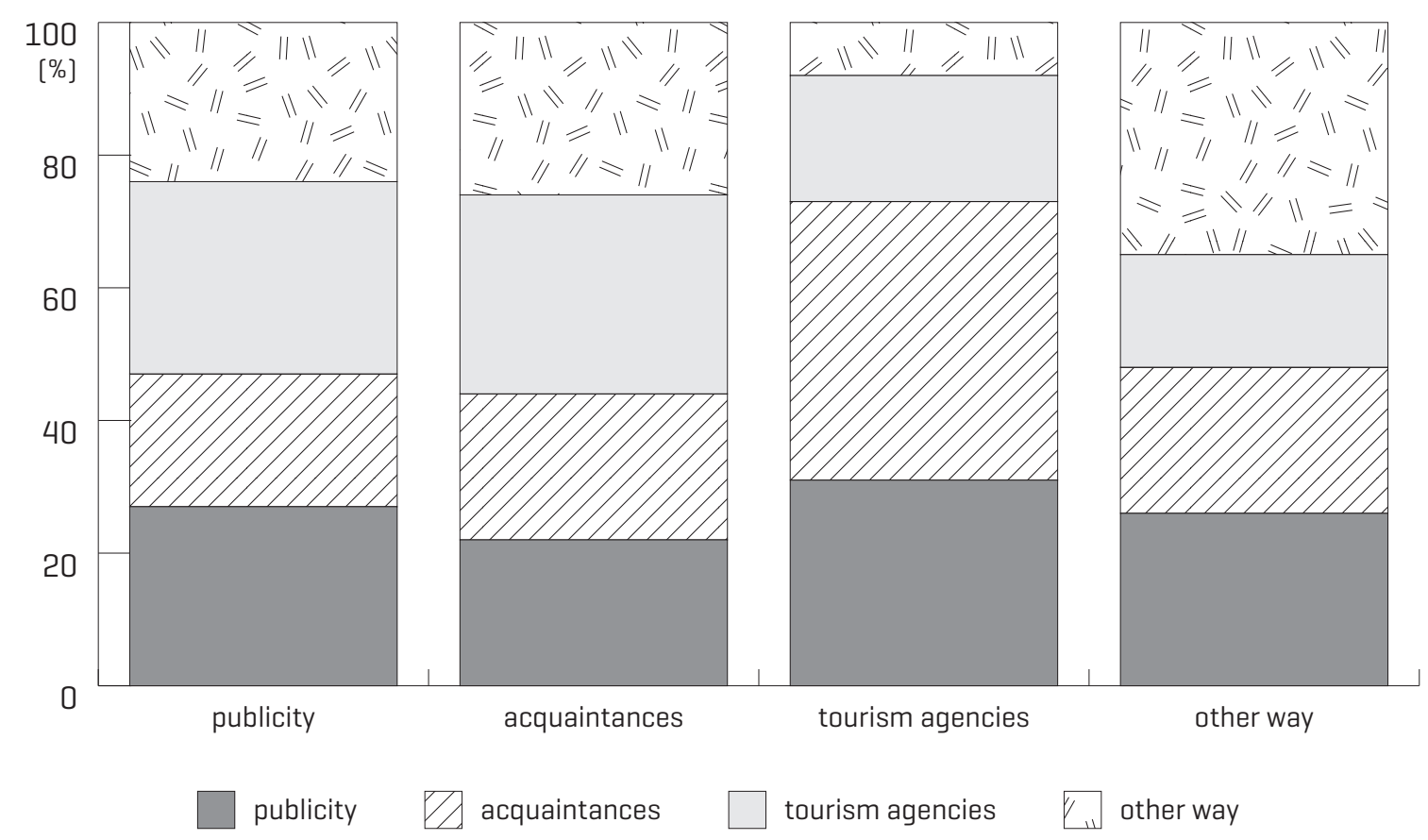

Figure 6. Ways of information on socio-professional groups at Geoagiu Spa 
ternational tourist experience shows that a tourist resort which reached a level of maturity in its development (like Geoagiu Spa), have to live actively 365 days in the 365 days of the year (at least theoretically), which presupposes the existence of sufficient opportunities of leisure for every tourist, according to their preferences and aspirations and a sufficiently elastic supply of services to be restructured quickly depending on natural conditions, the alternation of periods of seasonality, but also sufficient attractiveness to attract the interest of tourists to visit these stations at any time of year.

\section{Conclusions regarding the tourist phenomenon within the Geoagiu-băi spa}

The diversity and quality of the services represents one of the main factors of competitively and, consequently, a fundamental problem confronting the touristic industry in general. The regress, the stagnation or the prosperity of the entire tourist future activity depends on it.

The national and international tourist experience demonstrates the fact that a tourist place attaining a level of maturity in its development (as it is Geoagiu-Băi), has to live actively 365 days a year (at least theoretically speaking). This suppose the existence of numerous possibilities of spending time for each tourist, according to his preferences and aims, and a sufficiently flexible services offer that could be rapidly reshaped according to the existing natural conditions, to the periods of seasonal alternation. It also implies a sufficiently attractive offer to raise the tourists' interest to visit these places in any season of the year.

When analysing the essence of these principles, if we also take into consideration the tendencies recorded at the national level (and not only) of the continuous decrease of the medium stay span of a tourist in a spa, it becomes even more pressing the necessity of increasing in time the intensity of the touristic services offer in every spa, through a multitude of services conceived to allow the tourist to use each hour of his/her spare time in the most delightful way.

To attain this state of competitiveness, the following are recommended:

- to increase the number of one day trips that have as main destination the touristic sights from the region;

- to plan more trips that aims the visiting of some important cultural and historic places, of some monuments related to our historical past (the Costeşti Castle, the Grădiştea Muncelului Mountains and so on);

- to call touristic attention through advertising means with a view to exploit the existing technical-material resources;
- the granting of some facilities for the economic agents who organize youth camps;

- to promote incentives and facilities to attract the youth people on some important events of their life: marriages, honeymoon voyages, conferences on different topics, cultural events, symposiums;

- to diversify the offer of touristic routs with subjects activities: nature's curiosities; nature's protection;

- to organise different sport manifestations that include all the seasons;

- to attract the native and foreign investors by granting some financial and fiscal facilities;

- to include the spa in the international circuit of touristic programs.

In conclusion, the offer of services has to be sufficiently diverse to give tourists the possibility to spend their time in a pleasant way, on any occasion and situation. In the same time, this has to be flexible enough to allow the substitution of some activities with others that are easier to be carried on, but equally enjoyed by the tourists.

\section{References}

Ciangă, N. I980. Tourism in Alba County. Romanian Academy Press, Bucureşti, I58-I75.

Ciangă, N. I985. Tourism in Apuseni Mountains. Studia UBB, Geol. - Geogr., Cluj-Napoca, 67-73.

Ciangă, N. I987. The apparition and development of tourism in Carpathians. Studia UBB, Geol. Geogr., Cluj-Napoca, 69-73.

Ciangă, N. 200I. Tourism geography in Romania. Cluj University Press, Cluj-Napoca, 2or pp.

Cocean, P. I984. The economic potential of carst regions in Apuseni mountains. Romanian Academy Press, Bucureşti, I56 pp.

Cocean, P. 1988. Gorges and canyons in Apuseni Mountains. Romanian Academy Press, Bucureşti, I66 pp.

Cocean, P. I992. Models of tourism development in mountain regions in Romania. Studia $U B B$, Geographia I-2, I2I-I25.

Cocean, P. I997. Romanian tourism of geography. Edit. „Focul Viu”, Cluj-Napoca, I52 pp.

Cocean, P. 200o. Apuseni Mountains. Carst precesses and forms. Romanian Academy Press, Bucureşti, 235 pp.

Dombay, St. I994. Tourism geography. Edit. „Officina", Szeged, Hungary, 76 pp.

Dombay, Şt. I997. Genesis of volcanic landscape in view of global tectonics. Referate şi comunicări de geografie 4, 29-39.

Mac, I. I992. General tourism geography. Facultatea de Geografia Turismului, Sibiu, II7 pp.

Pop, Gr., Măhăra, Gh. I968. Făerag lake. Hydrographical aspects. Lucr. Ştiinţifice, vol. II, I05-II2. 